\title{
Adsorption and Reaction in Confined Spaces
}

\author{
J.F.M. Denayer', I. Daems' and G.V. Baron ${ }^{1}$ \\ 1 Dienst Chemische Ingenieurstechniek, Vrije Universiteit Brussel, Pleinlaan 2, B-1050 Brussel - Belgium \\ e-mail: joeri.denayer@vub.ac.be -ingdaems@vub.ac.be - grbaron@vub.ac.be
}

Résumé - Adsorption et réaction dans des espaces confinés - L'adsorption de molécules dans des matériaux microporeux cristallins implique des interactions énergétiques et entropiques spécifiques. L'assemblage moléculaire dans ces espaces confinés résulte dans des effets de sélectivité complètement différents des ceux qu'on observe traditionnellement avec des solides amorphes ou mésoporeux. Quelques exemples d'effets entropiques ou d'assemblage moléculaire dans l'adsorption d'hydrocarbures dans des zéolites sont présentés.

\begin{abstract}
Adsorption and Reaction in Confined Spaces - Adsorption of molecules in ordered microporous solids involves specific energetic and entropic effects. The molecular stacking in such confined spaces leads to selectivities different from those observed on traditional mesoporous or amorphous materials. Examples of packing and entropic effects in hydrocarbon adsorption on zeolites are presented. Rotational entropy driven separation of n-liso-alkane mixtures in zeolite MCM-22, inverse shape selectivity in SAPO-5, chain length induced selectivity reversal in ZSM-5 and stacking effects in the liquid phase separation of alkane/alkene mixtures on Faujasites are discussed. It is shown that entropy induced selectivity effects in the adsorption of alkane mixtures affect selectivity and isomer yield in hydro-isomerisation processes.
\end{abstract}




\section{INTRODUCTION}

Microporous solids such as zeolites are widely used in catalytic and separation processes. Such materials are very strong and selective adsorbents, so that molecules of different nature are adsorbed to a different extent $[1,2]$. Chain length, functional groups, molecular shape and so on are all factors which contribute to a different adsorption behaviour. According to the classical view on adsorption and zeolite catalysis, mainly energetic interactions govern the adsorption selectivity. For example, it is well accepted that in gas phase conditions at low degree of pore occupancy, longer hydrocarbon chains are adsorbed more selectively than their shorter homologues on most zeolites because of the larger interaction energy [3-6]. This results in the selective catalytic conversion of the longer chains from mixtures of short and long chains, which already demonstrates the link between adsorption and catalysis on microporous solids [7].

More recently, one starts realizing that entropic effects are often at least as important as energetic effects in the adsorption of molecules in confined environments [8,9]. This is certainly true for adsorption in liquid phase or at high pressure, where the organization and packing of molecules in the fully saturated zeolite pores becomes critical.

In this paper, several examples of unexpected (entropy driven) adsorption effects are discussed. Rotational entropy driven separation of $n$-/iso-alkane mixtures in cage forming zeolites, chain length induced selectivity reversal in intersecting pore systems and stacking effects in the liquid phase separation of alkane/alkene mixtures on Faujasites will be presented. Attention is devoted to the relation between entropy induced selectivity reversal in the adsorption of alkane mixtures and the selectivity and isomer yield in hydro-isomerisation processes in vapour and liquid phase conditions.

\section{INVERSE SHAPE SELECTIVITY IN TUBULAR PORES AND ZEOLITE CAGES}

According to conventional shape selectivity approaches, smaller molecular isomers (small in cross-section) are preferred over larger species in terms of adsorption equilibrium and kinetics. When saturated hydrocarbons are concerned, the less bulky linear alkane is preferentially adsorbed over its branched isomer inside a micropore [10-13]. This less favourable adsorption for the branched isomer is generally attributed to steric hindrance effects, preventing branched alkanes to adopt an "ideal" adsorptive configuration. However, preferential adsorption of branched hexane isomers (2,2-dimethylbutane and 3-methylpentane) from their mixture with n-hexane on SAPO-5 was observed experimentally by Santilli et al. [14]. Also recent molecular simulations showed inverse shape selectivity inside pores of microporous solids [15-18].
Here, two cases of inverse shape selectivity in the low coverage adsorption of $n$ - and iso-alkanes are reported. When considering hydrocarbon adsorption in zeolites, one could differentiate between two types of pore geometry: zeolites with tubular pore systems in which the translational motion of the molecules is not severely restricted but rotation of the molecules is as a result of the limited pore diameter, and zeolites with cages in which molecular rotation is possible but translation is restricted (Fig. 1). An example of the first class of zeolites is SAPO-5 with its pore system consisting of onedimensional, straight cylindrical channels of almost uniform cross-section of $c a .0 .72 \mathrm{~nm}$. When a mixture of $n$-pentane and 2-methylbutane is injected at the inlet of a column packed with SAPO-5 (Fig. 2), it occurs that the branched chain elutes later than its linear isomer, corresponding to inverse shape selectivity. Also for the $\mathrm{C}_{6}$ isomers, it was observed that 2,2-dimethylbutane retains significantly longer than $n$-hexane [19], which in turn retains longer than 2-methylpentane. This means that 2,2-dimethylbutane adsorbs preferentially over the latter two alkanes, whereas 2-methylpentane adsorbs less than its linear counterpart. None of the heptane isomers showed an inverse adsorption behaviour and out of 8 studied branched octane isomers, only 2,2-dimethylhexane adsorbed preferentially over its linear counterpart, although to a very small extent. The pores of SAPO-5 are in some cases more suitable for the linear molecules and in other cases favour the adsorption of the bulkier branched species.
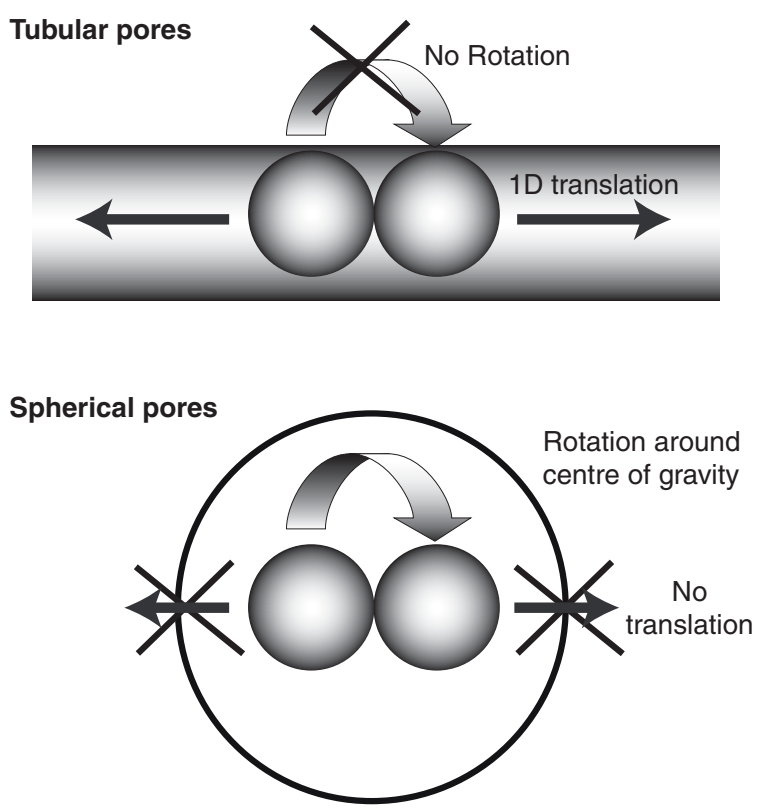

Figure 1

Schematical representation of (top) a tubular pore system in which translation of molecules occurs while rotation is restricted and (bottom) a zeolite cage in which the molecule is allowed to rotate around its centre of gravity whereas translation is limited. 


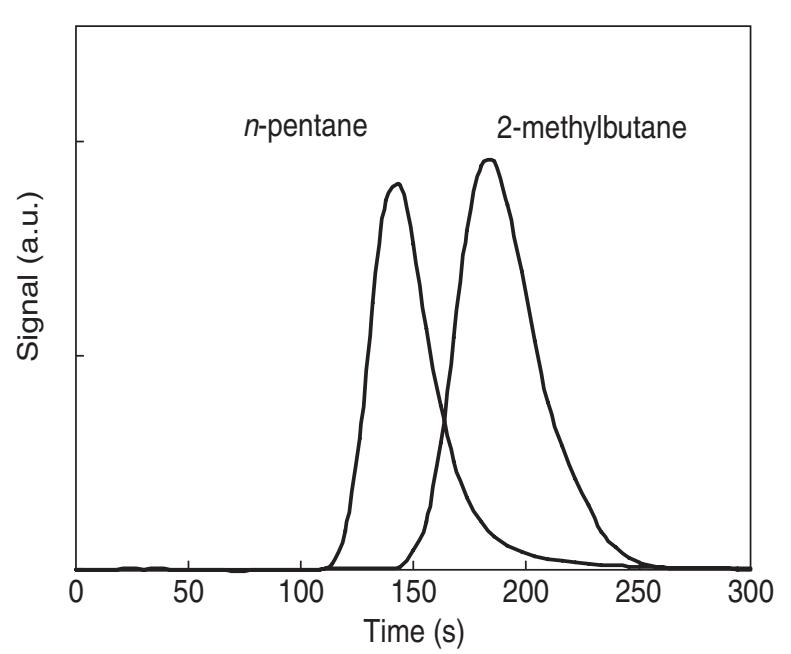

Figure 2

Chromatograms of $n$-pentane and 2-methylbutane on zeolite SAPO-5 $\left(150^{\circ} \mathrm{C}\right)$.

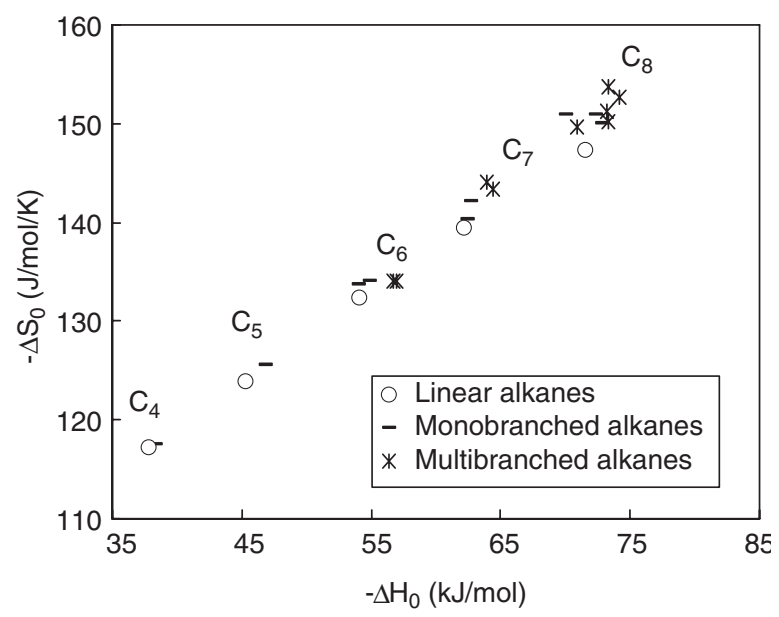

Figure 3

Compensation chart for SAPO-5.
In Figure 3, the adsorption entropy of all studied molecules is plotted as a function of the adsorption enthalpy. For a given alkane family, the compensation chart yields a straight line [20-22], meaning that the stronger a molecule interacts with the zeolite, the more freedom (entropy) it looses. At low occupancies, an adsorbed molecule experiences van der Waals (VDW) interactions with the pore walls. The strength of the VDW interactions depends on the distance between the atoms of the molecule and the pore walls and the number and type of atoms in the molecule. The closer the molecule approaches the pore walls, the higher these interactions. The freedom a molecule retains inside a zeolite micropore is governed by the strength of interaction and the ability to translate and rotate in the adsorbed state, which depends on the size and shape of the molecule and the pore topology. The individual contributions of enthalpy and entropy to the overall adsorption behaviour thus subtly depends on the steric fit between the guest molecule and the micropore.

Nearly all branched species have higher adsorption enthalpies when compared to their linear counterparts, thus the VDW forces for the branched molecule are higher than those for their linear counterparts. The critical diameter of a linear alkane chain is 4.3 Ångström, leaving a relatively large distance between the molecule and the SAPO-5 pore walls given its pore diameter of $7.3 \AA$. Side methyl groups on the alkane chain allow to obtain closer contact with the pore walls, and result in higher VDW interactions. It might also be expected that these side methyl groups with their 3 hydrogen atoms have a larger energetic interaction compared to the $-\mathrm{CH}_{2}$ groups in the main chain. For example, the critical diameter of 2,2-dimethylbutane is $6.3 \AA$, giving much closer contact.
Not all branched species exhibit inverse shape selectivity in spite of their energetic advantage. The reason for this is that branched molecules have a more negative adsorption entropy compared to the $n$-alkanes (Fig. 3). In the pores of SAPO-5, free rotation of both $n$ - and iso-alkanes from $\mathrm{C}_{5}$ on is not possible. Hence, no difference in rotational entropy between the isomers is expected. However, the presence of side groups on the chain reduces the translational freedom in the unidimensional SAPO-5 pores. Only those branched isomers having a more negative Gibbs energy than the $n$-alkanes will have a higher Henry adsorption equilibrium constant, and adsorb preferentially. This is the case for isobutane, 2-methylbutane, 3-methylpentane, 2,2-dimethylbutane and 2,3-dimethylbutane. For the other branched isomers, the gain in adsorption enthalpy compared to the linear chains is not large enough to compensate for the loss in entropy.

An example of a material with cages is zeolite MCM-22. This material contains large supercages with an inner free diameter of $0.71 \mathrm{~nm}$ and a inner height is $1.82 \mathrm{~nm}$ [23]. Besides, MCM-22 has a second pore system of 2-dimensional sinusoidal channels, which maintain an effective 10-ring diameter $(0.40 \times 0.55 \mathrm{~nm})$ throughout the structure. Also for this material, a preferential adsorption of certain isoalkanes over their linear isomers was observed [24]. For example, 2-methylbutane is significantly longer retained on a column packed with MCM-22 compared to $n$-pentane (Fig. 4). The compensation plot indicates that on this zeolite, monobranched alkanes loose less entropy upon adsorption which causes their preferential adsorption (Fig. 5). Linear and branched molecules adsorbed in the supercages will loose most of their translational freedom. However, differences in rotational freedom in the supercages of MCM-22 


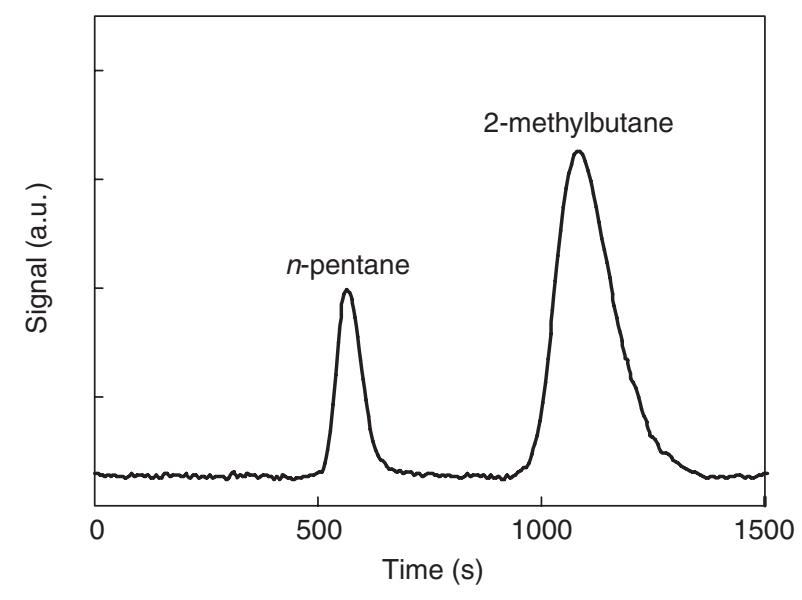

Figure 4

Chromatograms of a $n$-pentane and 2-methylbutane mixture on zeolite MCM-22 $\left(200^{\circ} \mathrm{C}\right)$



Figure 5

Compensation chart for linear and monobranched alkanes on MCM-22 (-ln $\left.\mathrm{K}_{0}{ }^{\prime} \sim-\Delta \mathrm{S}_{0}\right)$. may have a substantial impact on the adsorption equilibrium. Branched alkanes, with their shorter main carbon chain, need less space to rotate freely compared to the longer linear alkanes. For example, 2-methylbutane is able to freely rotate in the upper and lower part of the supercage, whereas rotation of $n$-pentane is already severely restricted (Fig. 6). As a result, 2-methylbutane has a more negative Gibbs energy of adsorption and thus higher adsorption equilibrium constant, in spite of its less negative adsorption enthalpy.

Summarising, iso-alkanes are preferentially adsorbed over linear alkanes in the tubular pores of SAPO-5, because of the more favourable energetic interaction of the branched alkanes with the pore walls of SAPO-5, while in the cages of MCM-22, iso-alkanes are preferentially adsorbed because they loose less (rotational) entropy.

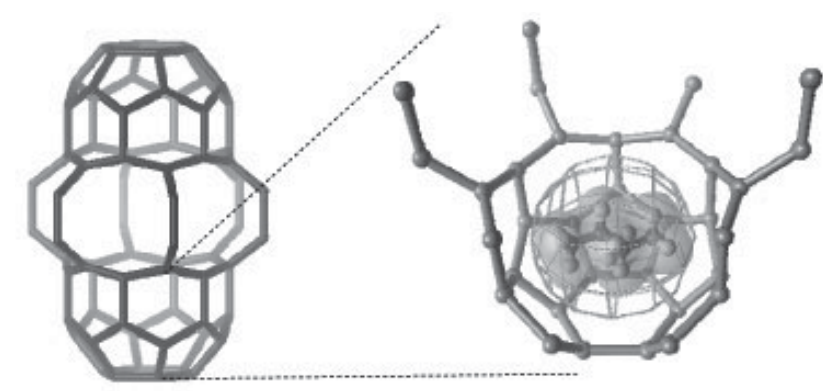

Figure 6

MCM-22 supercage and 2-methylbutane molecule with its gyration sphere in the bottom pocket of the supercage.

\section{CHAIN LENGTH INDUCED SELECTIVITY REVERSAL IN ZSM-5}

The adsorption of the homologous alkane series in gas phase on zeolites and other adsorbents has been extensively studied by many researchers. The existence of linear relationships between adsorption enthalpy and entropy, and the carbon number has been demonstrated numerously [3, 25-27]. Among all zeolites, ZSM-5 is undoubtedly the most studied one, both from the adsorption and catalysis point of view. Several experimental studies reported the occurrence of a kink in the pure component adsorption isotherms of alkanes in gas phase on ZSM-5 [28-30], and an inflection point in the adsorption enthalpy and entropy versus zeolite loading curves [31, 32]. Generally, the two-step behaviour of these linear and branched alkanes is interpreted in terms of the ZSM-5 channel geometry. For example, it has been observed that at low partial pressures, isobutane is adsorbed preferentially in the channel intersections of ZSM-5, while at higher pressures, these branched molecules are "pushed" into the channel segments, resulting in a significant loss of entropy and a kink in the adsorption isotherm [33]. The importance of entropy effects in the adsorption of alkanes on ZSM-5 has been demonstrated by computational techniques [34-36].

Also in liquid phase, remarkable chain length dependent adsorption effects have been observed on ZSM-5 [37-39]. Figure 7 shows the adsorption saturation capacity of the $\mathrm{C}_{5^{-}}$ $\mathrm{C}_{22}$ n-alkanes, expressed in number of molecules and total number of $-\mathrm{CH}_{\mathrm{x}}$ groups adsorbed per unit cell. A drop in number of molecules adsorbed per unit cell is observed between $\mathrm{C}_{6}$ and $\mathrm{C}_{8}$. From $\mathrm{C}_{8}$ on, the number of molecules adsorbed per unit cell decreases gradually. For $\mathrm{C}_{5}$, a unit cell contains $36-\mathrm{CH}_{\mathrm{x}}$ groups, for $\mathrm{C}_{6}$ and $\mathrm{C}_{7} 44-\mathrm{CH}_{\mathrm{x}}$ groups are adsorbed per unit cell, while for $\mathrm{C}_{8}$, only $32-\mathrm{CH}_{\mathrm{x}}$ groups are 
adsorbed per unit cell. From $\mathrm{C}_{8}$ on, the number of $-\mathrm{CH}_{\mathrm{x}}$ groups per unit cell increases steadily, to reach a maximum of about 51-52 $-\mathrm{CH}_{\mathrm{x}}$ groups per unit cell from $\mathrm{C}_{14}$ on. For molecules shorter than $\mathrm{C}_{14}$, it appears that the available space in the pores of ZSM-5 is thus not completely used, and gaps must be present between the adsorbed molecules. A calculation of the total occupied length of the adsorbed n-alkane molecules (taking into account the repulsion between $-\mathrm{CH}_{\mathrm{x}}$ groups from neighbouring molecules) shows the same tendency [38].

The packing mechanisms of the $n$-alkanes were studied by configurational-bias GCMC calculations [39]. Pentane and hexane have lengths less than the distance between intersections, and occupy the channel space between 2 intersections. Longer chains cross the intersection and extend into adjacent channel space, leading to a less efficient pore filling. With increasing chain length, the $n$-alkanes become more flexible, and can bend such that they start in e.g. a linear channel segment and end in a sinusoidal channel segment. From $\mathrm{C}_{13}$ on, the molecules are flexible enough to completely fill up the pore system.

These differences in packing mechanisms between alkanes of different chain length lead to irregular selectivity patterns. Compositions in the adsorbed phase are plotted versus the compositions of the external liquid phase for selected binary alkane mixtures in Figure 8 . In some cases, preferential adsorption of the longest alkane chain was observed (e.g. $\mathrm{C}_{9} / \mathrm{C}_{13}$ ). With $\mathrm{C}_{6} / \mathrm{C}_{10}$ and $\mathrm{C}_{5} / \mathrm{C}_{7}$, reversal of selectivity occurs at a specific composition where adsorbate and liquid have identical composition. Finally, for $\mathrm{C}_{14} / \mathrm{C}_{15}$ and $\mathrm{C}_{15} / \mathrm{C}_{16}$, the lightest alkane was selectively adsorbed.
This remarkable adsorption selectivity is the result of a special organization of the $n$-alkane molecules. The strong interaction with the pore walls implies a high adsorption enthalpy, but also a significant loss of entropy. At high loading, the dense packing of the molecules limits the reorganization capabilities of individual molecules in the adsorbate phase. The complete filling of the two-dimensional pore system of ZSM- 5 by long alkanes requires a very high flexibility and degree of organization. Pronounced adsorption selectivity for the short chain is observed with $\mathrm{C}_{14} / \mathrm{C}_{15}$ and $\mathrm{C}_{15} / \mathrm{C}_{16}$. The chain length of $\mathrm{C}_{14}$ corresponds to the length of two sinusoidal channel segments and an intersection, but also fits into two linear channel segments and two intersections. The length of a $\mathrm{C}_{15}$ molecule exceeds the dimensions of two sinusoidal channel segments and an intersection but still fits into two linear channel segments and two intersections. A stretched $\mathrm{C}_{16}$ molecule does not fit into neither of these combinations, and thus always blocks an additional intersection compared to $\mathrm{C}_{15}$ or $\mathrm{C}_{14}$. The favourable adsorption of $\mathrm{C}_{14}$ and $\mathrm{C}_{15}$ is ascribed to this matching with characteristic dimensions of the pore system. The adsorption of mixtures containing $\mathrm{C}_{5}$ or $\mathrm{C}_{6}$ can be explained in a similar way. These molecules fit neatly into a sinusoidal channel segment, whereas longer alkanes block intersections. Admixing $\mathrm{C}_{5}$ or $\mathrm{C}_{6}$ with a longer alkane fitting less well with characteristic pore length gives rise to azeotrope behavior (e.g. $\mathrm{C}_{5} / \mathrm{C}_{7}, \mathrm{C}_{6} / \mathrm{C}_{10}$ ). These mixtures fill the pores only partially. At low concentration of the long chain, it is preferentially adsorbed due to its higher adsorption enthalpy. From a critical concentration of these long chains on, $\mathrm{C}_{5}$ or $\mathrm{C}_{6}$ adsorption is preferred because of their better fitting with the sinusoidal channels.

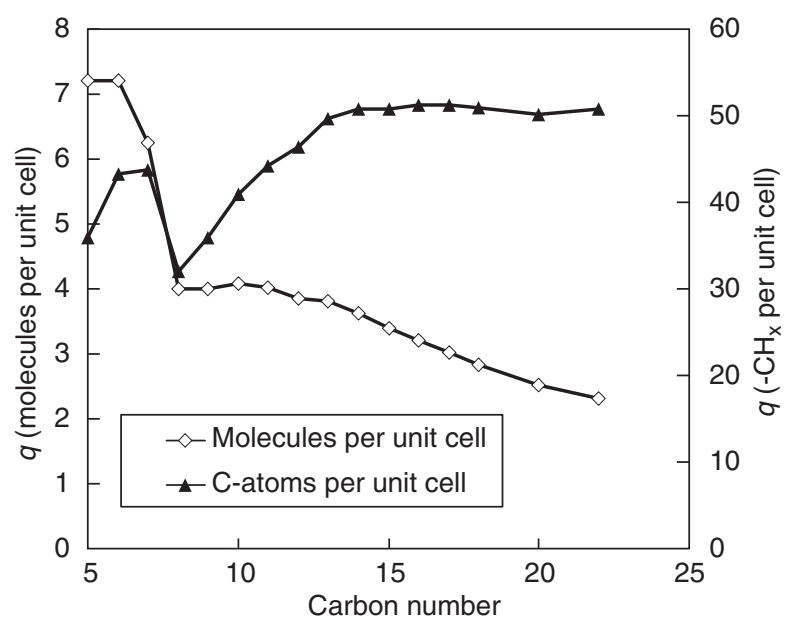

Figure 7

Saturation capacity of the $\mathrm{C}_{5}-\mathrm{C}_{22} n$-alkanes, expressed in number of molecules and total number of carbon atoms adsorbed per unit cell.

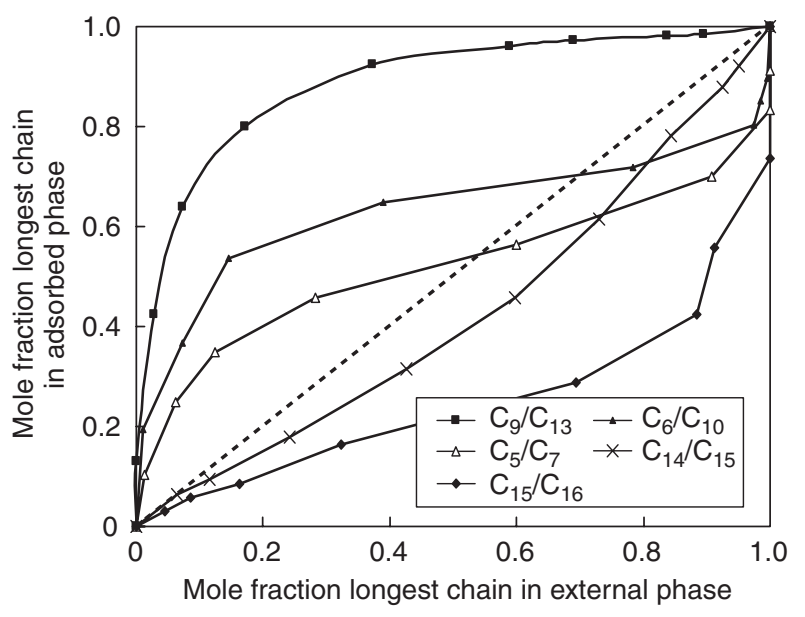

Figure 8

Selectivity diagrams for binary $n$-alkane mixture adsorption in ZSM-5. 


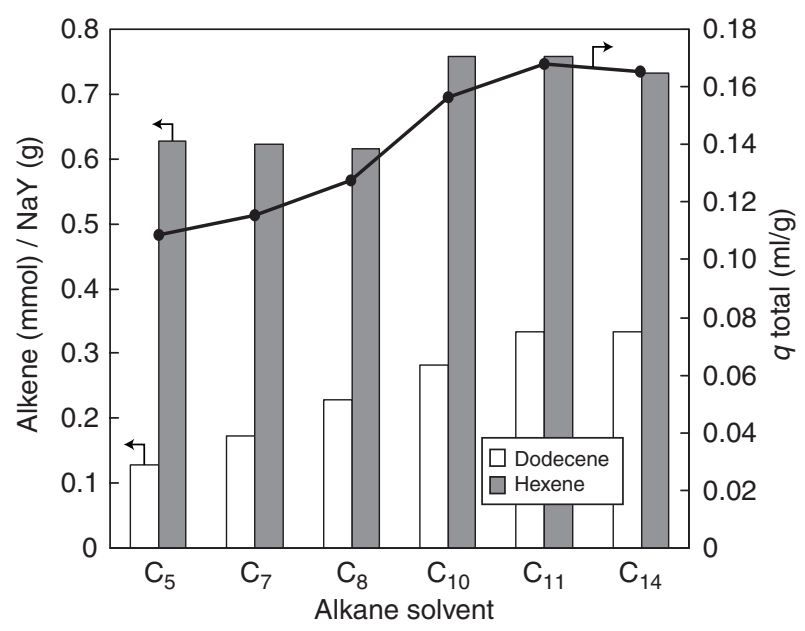

Figure 9

Liquid phase adsorption of an equimolar hexene/dodecene mixture $(2 \mathrm{~mol} \%)$ from alkane solvents $(96 \mathrm{~mol} \%)$ on $\mathrm{NaY}$ (room temperature).

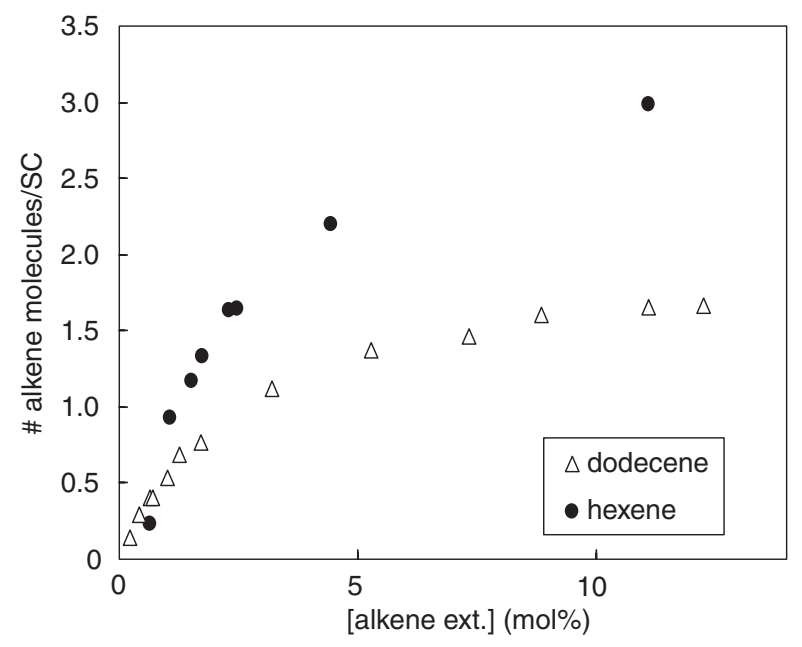

Figure 10

Adsorption isotherms of hexene and dodecene from their mixture with decane on $\mathrm{NaY}$ (room temperature).
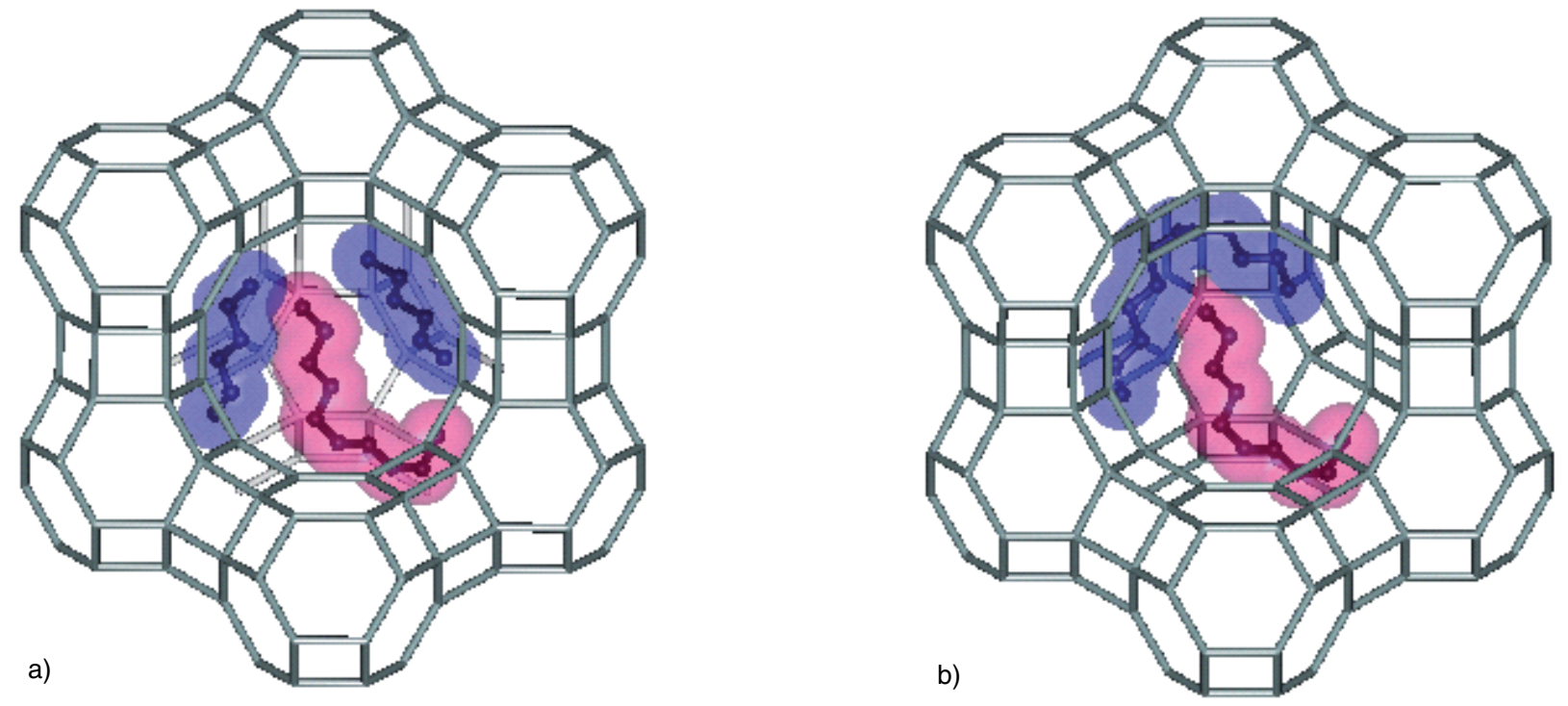

Figure 11

Schematic presentation of the coadsorption of (left) hexene and decane and (right) dodecene and decane in a NaY supercage at an external alkene concentration of $3 \mathrm{~mol} \%$.

\section{PACKING EFFECTS IN THE ADSORPTION OF ALKANES/ALKENES/AROMATICS}

The gas phase adsorption of alkanes, alkenes and aromatics on faujasites in has been studied frequently [40-53]. Generally, alkenes and aromatics are more strongly adsorbed compared to the apolar alkanes because of their electrostatic interactions with the zeolite cations. Further, it is accepted that an increase in cation-content (decrease in $\mathrm{Si}: \mathrm{Al}$ ) increases the selectivity of adsorption of aromatics, alkenes and even alkanes in gas phase conditions [54-57]. In contrast, the adsorption of mixtures of alkanes, alkenes and aromatics in liquid phase and the effect of cation content thereon is poorly documented $[58,59]$.

The adsorption of alkenes with different chain length $\left(\mathrm{C}_{6}-\mathrm{C}_{12}\right)$ from alkane solvents $\left(\mathrm{C}_{5}-\mathrm{C}_{14}\right)$ on $\mathrm{NaY}$ ( $\left.\mathrm{Si}: \mathrm{Al} 2.79\right)$ was studied using a batch experimental technique [60-62]. Under these conditions the zeolite micropores are close to saturation, since the solvent (alkane) will show tendency to fill up the remaining free space. Already at low alkene 
concentrations, the alkenes are selectively adsorbed from their mixture with an alkane as a result of the electrostatic interaction of the double bond with the zeolite cations.

The amount of alkene adsorbed depends on the chain length of both the alkene and the alkane solvent. Two remarkable effects are observed:

- shorter alkenes are preferentially adsorbed compared to longer alkenes (Fig. 10);

- with shorter alkanes, the alkene selectivity decreases (Fig. 9).

These observations are in conflict with the increase in adsorption with carbon number as observed in gas-phase conditions. Apparently, shorter linear hydrocarbons, having a smaller number of C-atoms pack more efficiently at higher loading and are in other words favourably adsorbed because they can easily fill gaps within the zeolite matrix. Such an effect was not expected to occur on cage-type zeolites capable of hosting multiple molecules per supercage. The adsorption of hexene and decene from their mixture with decane at an external alkene concentration of $3 \mathrm{~mol} \%$ is schematically presented in Figure 11. The empty space next to one decane molecule can be filled with either two hexene or one dodecene molecule(s), leading to a more selective adsorption of hexene compared to dodecene (Fig. 11).

\section{SELECTIVITY ENHANCEMENT IN HYDRO-ISOMERISATION PROCESSES VIA ADSORPTION EFFECTS}

At low zeolite loading, in gas or vapour phase conditions (low pressure), long alkanes are selectively adsorbed over shorter ones (vide supra). In catalytic processes with mixtures of long and short alkanes using zeolites, this often leads to high reactivities of the heaviest components of the mixtures, whereas the lightest components are nearly not converted as they are not adsorbed inside the catalyst pores $[63,64]$. With increasing zeolite loading, the differences in adsorption between short and long alkanes decrease. At very high pressure or in liquid phase conditions when the zeolite pores are densely filled with molecules, adsorption of the shorter alkanes is even favoured over longer ones since the shorter molecules can be packed more easily $[65,66]$. This adsorption effect can be used to modify reactivity and selectivity in catalytic processes [67-69]. In Figure 12, the hydroconversion of nonane and heptane on zeolite $\mathrm{Pt} / \mathrm{HY}$ is shown as a function of the average mixture conversion for the liquid and vapour phase conditions at $250^{\circ} \mathrm{C}$. In vapour phase (low pressure), nonane is converted much more rapidly than heptane, which should be attributed to its preferential adsorption. Initially, the pores of the catalyst mainly contain nonane, which is converted into its products. With increasing degree of conversion (increasing space time), the reaction mixture becomes depleted in nonane, and heptane starts to adsorb in the zeolite pores where it is converted into its isomers and cracked products. In liquid phase at 100 bar, the conversion rate of nonane is only slightly higher than that of heptane, and the competition effects between both components are significantly lower compared to the vapour phase. In these conditions, adsorption of heptane is favoured compared to gas phase conditions resulting in its higher conversion. The operating conditions also have a large effect on the reaction selectivity. Yield curves for the hydroconversion of an equimolar heptane/nonane mixture in vapour and liquid

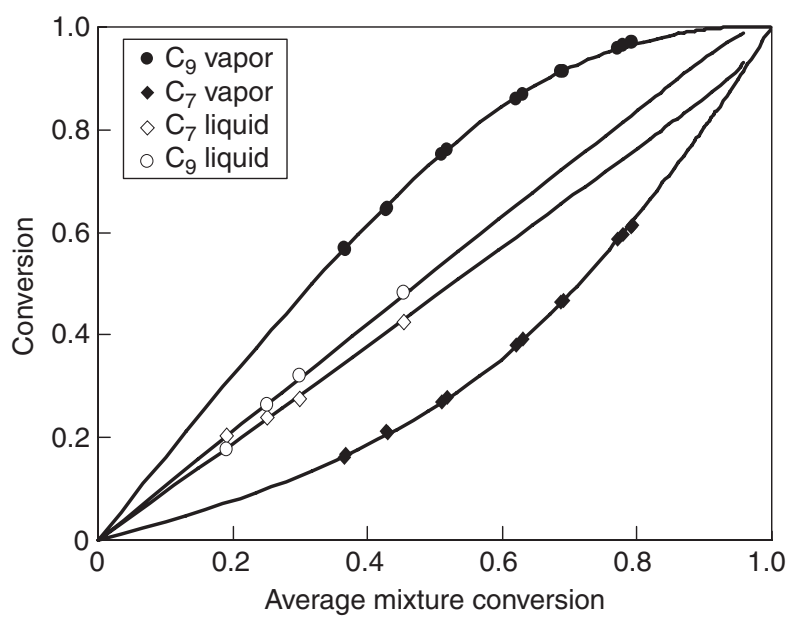

Figure 12

Conversion of nonane and heptane on zeolite $\mathrm{Pt} / \mathrm{HY}$ as a function of the average mixture conversion in vapour (total pressure: 4.5 bar) and liquid phase (total pressure: 100 bar) at $250^{\circ} \mathrm{C}$.

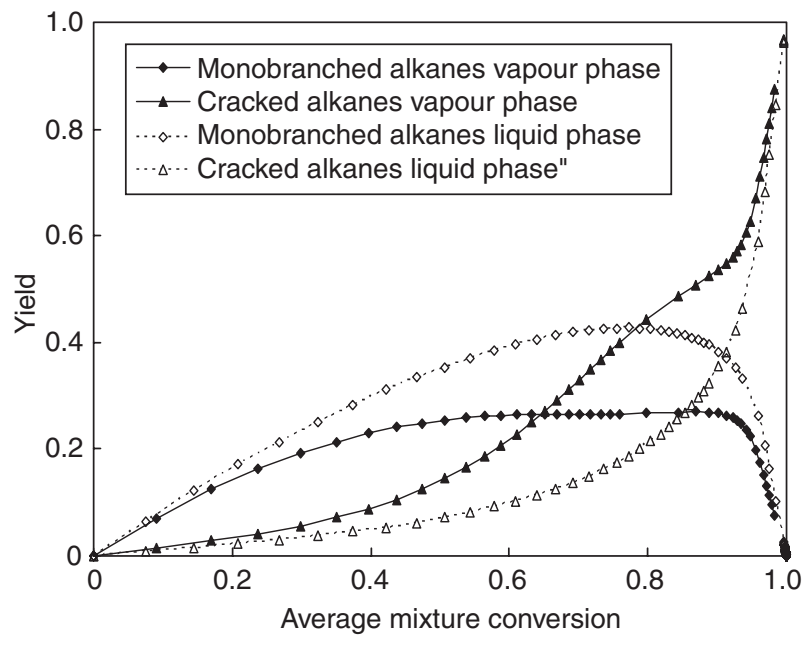

Figure 13

Monobranched and cracked alkane yield in the hydroconversion of an equimolar heptane/nonane mixture on $\mathrm{Pt} / \mathrm{H}-\mathrm{Y}$ (Total pressure in vapour phase: 4.5 bar, hydrocarbon pressure in vapour phase: 0.32 bar; total pressure in liquid phase: 100 bar). 
phase conditions are given in Figure 13. At high pressure in liquid phase, a significantly higher yield of isomers is obtained. In vapour phase, nonane is selectively adsorbed and converted almost completely into (weakly adsorbing) cracked products before adsorption and conversion of heptane starts. Light cracking products are already formed at low average conversions. In liquid phase contrarily, heptane and nonane are adsorbed simultaneously from the lowest level of conversion on, thus isomers of both heptane and nonane are formed at low contact times. Cracking of both components starts at relatively high average conversion levels, when they are already transformed into iso-alkanes. Operating at high pressure in liquid phase thus allows to obtain higher isomerate yields at lower reactor severities.

\section{CONCLUSIONS}

The adsorption of hydrocarbons in microporous solids is governed by a combination of enthalpic and entropic effects. Large energetic interactions between molecular structures (e.g. double bond of alkene of aromatic ring) and adsorption sites, lead to a preferential adsorption of specific species. Entropic packing effects at high degree of pore filling on the other hand clearly outweigh normal tendencies based on adsorbate properties (\# C-atoms) and structural properties (aluminium contents) observed at low coverage. Even in adsorbents or catalysts with relatively large micropores, molecular selectivity is achieved at high degree of pore occupancy as a result of the organisation of molecular assemblies in such confined spaces. These selectivity effects depend in a subtle way on molecular size and shape, functional groups, pore size end geometry, presence of solvents and so on. This concept of packing induced selectivity offers perspectives for new or optimised catalytic and/or separation processes.

\section{ACKNOWLEDGEMENTS}

J. Denayer is grateful to the F.W.O.-Vlaanderen, for a fellowship as postdoctoral researcher. The authors are grateful to the Institut Français du Pétrole for financial support.

\section{REFERENCES}

1 Van Bekkum, H., Flanigen, E.M., Jacobs, P.A., Jansen, J.C. (2001) Stud. Surf. Sci. Catal., 137, 663-668.

2 Chen, N.Y, Garwood, W.E., Dwyer, F.G. (1989) Shape selective catalysis in industrial applications, Marcel Dekker, New York.

3 Eder, F., Stockenhuber, M., Lercher, J.A. (1997) J. Phys. Chem. B 1997, 101, 5414-5419.

4 Katsanos, N.A. (1978) J. Chem. Soc. Faraday T., 74, 575582; Wang, Y., Davis, B.H., Tungate, F.L. (1999) ACS Sym. Ser., 738, 145-159.

5 Okamura, J.P. (1971) Anal. Chem., 43, 1730-1733.
6 Denayer, J.F., Baron, G.V., Martens, J.A., Jacobs, P.A. (1998) J. Phys. Chem. B, 102, 3077-3081.

7 Denayer, J.F.M., Ocakoglu, R.A., Huybrechts, W., Dejonckheere, B., Martens, J.A., Jacobs, P.A., Calero, S., Krishna, R., Smit, B., Baron, G.V. (2003) High pressure liquid phase hydroconversion of heptane/nonane mixture on $\mathrm{Pt} / \mathrm{H}-\mathrm{Y}$ zeolite catalyst, J. Catal., 220, 66-73.

8 Calero, S., Schenk, M., Smit, B., Maesen, T.L.M. (2004) J. Catal., 221, 241-251.

9 Schenk, M., Calero, S., Maesen, T.L.M., Van Benthem, L.L., Verbeek, M.G., Smit, B. (2002) Angew. Chem. Int. Edit., 41, 2499-2502.

10 Cavalcante, J., Ruthven, D.M. (1995) Ind. Eng. Chem. Res., 34, 177-184.

11 Funke, H.H., Argo, A.M., Falconer, J.L., Noble, R.D. (1997) Ind. Eng. Chem. Res., 36, 137-143.

12 Huddersman, K., Klimczyk, M. (1996) AICHE J., 42, 405408.

13 Denayer, J.F., Souverijns, W., Jacobs, P.A., Martens, J.A., Baron, G.V. (1998) J. Phys. Chem. B, 102, 4588-4597.

14 Santilli, D.S., Harris, T.V., Zones, S.I. (1993) Microporous Mater., 1, 329-341.

15 Fox, J.P., Bates, S.P. (2004) J. Phys. Chem. B, 108, 1713617142.

16 Lu, L., Wang, Q., Liu, Y. (2005) J. Phys. Chem. B, 109, 8845-8851.

17 Schenk, M., Calero, S., Van Benthem, L.L., Verbeek, M.G., Schnell, B., Smit, B. Maesen, T.L.M., Vlugt, T.J.H. (2003) J. Catal., 214, 88-99.

18 Chempath, S., Snurr, R.Q., Denayer, J.F.M., Baron, G.V. (2004) Stud. Surf. Sci. Catal., 154, 1983-1990.

19 Denayer, J.F.M., Ocakoglu, A.R., Martens, J.A., Baron, G.V. (2004) J. Catal., 240-244.

20 Ruthven, D.M., Kumar, R. (1980) Ind. Eng. Chem. Fund., 19, 27-32.

21 Hyun, S.H., Danner, R.P. (1985) AICHE J., 31, 1077-1085.

22 Ocakoglu, A.R., Denayer, J.F.M., Marin, G.B., Martens, J.A., Baron, G.V. (2003) J. Phys. Chem B, 107, 398-406.

23 Lawton, S.L., Leonowicz, M.E., Partridge, R.D., Chu, P., Rubin, M.K. (1998) Micropor. Mesopor. Mat., 23, 109-117.

24 Denayer, J.F.M., Ocakoglu, R.A., Arik, I.C., Kirschhock, C.E.A., Martens, J.A., Baron, G.V. (2005) Angew. Chem. Int. Edit., 44, , 400-403.

25 Bond, C.G., Keane, M.A., Kral, H., Lercher, J.A. (2000) Catal. Rev., 42, 323-383.

26 Ruthven, D.M., Kaul, B.K. (1998) Adsorption, 4, 269-273.

27 Hampson, J.A., Jasra, R.V., Rees, L.V.C. (1991) Stud. Surf. Sci. Catal., 62, 509-517.

28 Richards, R.E., Rees, L.V.C. (1987) Langmuir, 3, 335-340.

29 Zhu, W., van der Graaf, J.M., van den Broeke, L.J.P., Kapteijn, F., Moulijn, J.A., (1998) Ind. Eng. Chem. Res., 37, 1934-1942.

30 Sun, M.S., Talu, O., Shah, D.B., (1996) J. Phys. Chem., 100, 17276-17280.

31 Yang, Y., Rees, L.V.C., (1997) Microporous Mater., 12, 117-122.

32 Millot, B., Methivier, A., Jobic, H. (1998) J. Phys. Chem. B, 102, 3210-3215.

33 Zhu, W., Kapteijn, F., Moulijn, J.A. (2000) Phys. Chem. Chem. Phys., 2, 1989-1995. 
34 Maginn, E.J., Bell, A.T., Theodorou, D.N. (1995) J. Phys. Chem., 99, 2057-2079.

35 Smit, B., Siepmann, J.I. (1994) J. Phys. Chem, 98, 8442-8452.

36 Krishna, R., Paschek, D. (2001) Phys. Chem. Chem. Phys., 3, 453-462.

37 Denayer, J.F.M., De Meyer, K., Martens, J.A., Baron, G.V. (2003) Angew. Chem.-Ger. Edit., 42, 2774-2777.

38 De Meyer, K., Chempath, S, Denayer, J.F.M., Martens, J.A., Snurr, R.Q., Baron, G.V. (2003) J. Phys. Chem. B., 107, 10760-10766.

39 Chempath, S., de Meyer, K., Denayer, J.F.M, Baron, G.V., Snurr, R.Q. (2004) Langmuir, 20, 150-156.

40 Harlfinger, R., Hoppach, D., Hofmann, H.-P. (1980) Z. Phys. Chem., 261, 33.

41 Palmas, S., Polcaro, A.M., Carta, R., Tola, G. (1991) J. Chem. Eng. Data, 36, 1.

42 Da Silva, F.A., Rodrigues, A.E. (1999) Ind. Eng. Chem. Res., 38, 2051.

43 İnel, O., Topaloğlu, D., Asskin, A., Tümsek, F. (2002) Chem. Eng.J., 88, 255.

44 Miyano, Y., Nakanishi, K., Fukuchi, K. (2003) Fluid Phase Equilibr., 208, 223.

45 Jentys, A., Mukti, R.R., Tanaka, H., Lercher, J.A. (2006) Micropor. Mesopor. Mat., 90, 284-292.

46 Atkinson, D., Curthoys, G. (1981) J. Chem. Soc. Faraday T., $1,897$.

47 Stach, H., Lohse, U., Thamm, H., Schirmer, W. (1986) Zeolites, 6, 74.

48 Denayer, J.F.M., Baron, G.V. (1997) Adsorption, 3, 251.

49 Eder, F., Lercher, J.A. (1997) Zeolites, 18, 75.

50 Bezus, A.G., Kiselev, A.V., Du, P.Q. (1972) J. Colloid Interf. Sci., 40, 223.

51 Hampson, J.A., Rees, L.V.C. (1994) in: Hattori, T., Yashima, T. (Eds.), Stud. Surf. Sci. Catal., 83, 197.

52 Choudhary, V.R., Mayadevi, S. (1993) Separ. Sci. Technol., 28, 1595.
53 Pascual, P., Ungerer, P., Tavitian, B., Boutin, A. (2004) J. Phys. Chem. B, 108, 393.

54 Barthomeuf, D., Ha, B.-H. (1973) J. Chem. Soc. Faraday Trans. 1, 12, 2158.

55 Dzhigit, O.M., Kiselev, A.V., Rachmanova, T.A. (1984) Zeolites, 4, 389.

56 Jänchen, J., Stach, H. (1985) Zeolites, 5, 57.

57 Papaioannou, Chr., Petroutsos, G., Gunßer, W. (1997) Solid State Ionics, 101-103, 799.

58 Herden, H ., Einicke, W.D., Schöllner, R. (1981) J. Colloid Interf. Sci., 79, 280.

59 Herden, H., Einicke, W.D., Messow, U., Quitzscj, K., Schöllner, R. (1982) Chem. Technol., 34, 364.

60 Daems, I., Leflaive, P., Méthivier, A., Denayer, J.F.M., Baron, G.V. (2005) Adsorption, 11, 189-194.

61 Daems, I., Leflaive, P., Méthivier, A., Denayer, J.F.M., Baron, G.V. (2005) Micropor. Mesopor. Mat., 82, 191-199.

62 Daems, I., Méthivier, A., Leflaive, P., Fuchs, A.H., Baron, G.V., Denayer, J.F.M. (2005) J. Am. Chem. Soc., 127, 1160011601 .

63 Steijns, M., Froment, G.F. (1981) Ind. Eng. Chem. Prod. Res. Dev., 20, 660-668.

64 Dauns, H., Weitkamp, J. (1986) Chem. Ing. Tech., 11, 900-902.

65 Calero, S., Smit, B., Krishna, R. (2001), Phys. Chem. Chem. Phys., 3, 4390-4398.

66 Talbot, J. (1997), AICHE J., 43, 2471.

67 Denayer, J.F.M., De Jonckheere, B., Hloch, M., Marin, G.B., Vanbutsele, G., Martens, J.A., Baron, G.V. (2002) J. Catal., 210, 445-452.

68 Denayer, J.F.M., Ocakoglu, R.A., Huybrechts, W., Dejonckheere, B., Martens, J.A., Jacobs, P.A., Calero, S., Krishna, R., Smit, B. Baron, G.V. (2003) J. Catal., 220, 66-73.

69 Denayer, J.F.M., Ocakoglu, R.A., De Jonckheere, B., Martens, J.A., Thybaut, J.W., Marin, G.B., Baron, G.V. (2003) Int. J. Chem. React. Eng., 1, A36.

Final manuscript received in June 2006

Copyright $(\odot 2006$ Institut français du pétrole

Permission to make digital or hard copies of part or all of this work for personal or classroom use is granted without fee provided that copies are not made or distributed for profit or commercial advantage and that copies bear this notice and the full citation on the first page. Copyrights for components of this work owned by others than IFP must be honored. Abstracting with credit is permitted. To copy otherwise, to republish, to post on servers, or to redistribute to lists, requires prior specific permission and/or a fee: Request permission from Documentation, Institut français du pétrole, fax. +33147527078 , or revueogst@ifp.fr. 